CRITICAL $\mid$\begin{tabular}{l|l|} 
ECOSYSTEM & Western Ghats \\
PARTNERSHIP FUND & Special Series \\
\hline
\end{tabular}

\section{ON THE OCCURRENCE OF MEMECYLON CLARKEANUM COGN. (MELASTOMATACEAE) - A VULNERABLE SPECIES FROM NILGIRIS, TAMIL NADU, INDIA}

\author{
C. Udhayavani ${ }^{1} \&$ V.S. Ramachandran ${ }^{2}$ \\ 1,2 Taxonomy \& Floristic Lab, Department of Botany, Bharathiar University, \\ Coimbatore, Tamil Nadu 641046, India \\ ${ }^{1}$ c.udhayavani@gmail.com (corresponding author), ${ }^{2}$ vsrbotany@gmail.com
}

The genus Memecylon L. (Melastomataceae) is widely distributed in the old world tropics and consists of ca. 250 species in the world (Mabberley 2008; Bremer $1979,1987)$. They are generally small trees or shrubs, mostly occurring in the understorey of evergreen forests. Clarke (1879) reported 40 species from erstwhile British India. Out of these, Gamble (1919) reported 18 species from Madras Presidency and Cooke (1901) reported five species from Bombay Presidency in peninsular India. Vivekananthan (1983) recorded 16 species from Tamil Nadu. Sasidharan (2004) recorded 18 species from the adjoining state of Kerala. Recent enumeration reveals that 39 taxa of this genus are now known from India, of which 21 are endemics (Murugan \& Gopalan 2006). In India, the Western Ghats is the major centre of diversity with 27 species, including 20 endemics confined to this 'hotspot' of biodiversity (Mohanan et al. 2001; Viswanathan \& Manikandan 2001; Kumar et al. 2003;
Manickam et al. 2007; Sivu et al. 2012).

While working on the floristic studies on the Gudalur and Pandalur taluks of Nilgiri District in Tamil Nadu, the authors could collect an interesting plant specimen of Memecylon L. from Devala, Nilgiri District (Fig. 1, Images

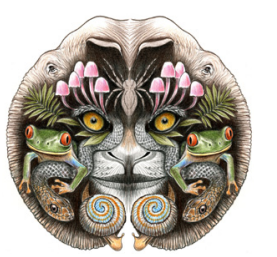

ISSN

Online 0974-7907 Print 0974-7893

OPEN ACCESS $1,2)$. The specimen was critically studied and various characteristic features were examined. There was no match with any known species from Tamil Nadu. After further scrutiny of the specimen as well as the available literature, it was identified as Memecylon clarkeanum Cogn. This species was so far known as endemic to Sri Lanka, until Sivu et al. (2012) reported it from Wyanad, Kozhikode, Malappuram and Palakkad districts of Kerala. The present collection of this rare species from Tamil Nadu forms a new record for Tamil Nadu and it further strengthens the phytogeographic affinities of Sri Lanka and peninsular India. The detailed description, phenology, distribution along with an illustration are also provided to facilitate easy identification of this plant. The specimen cited is deposited in the Bharathiar University Herbarium (BU 5325), Department of Botany, Bharathiar University, Coimbatore, Tamil Nadu for future reference (Image 3).

Memecylon clarkeanum Cogn. (Fig. 1, Image 1)

in DC., Mon. Phan. 7: 1141. 1891; Trimen, Handb. Fl. Ceylon 2: 217. 1894; Bremer, Opera Bot. 50:24. 1979; Dassanayake \& Fosberg, A Revised Handb. Fl. Ceylon 6: 227.1987; Sivu et al., Taiwania, 57(3): 327-330. 2012. Memecylon heyneanum Benth. in Wall. ex Wight \& Arn.

DOI: http://dx.doi.org/10.11609/JoTT.03638.4811-3

Editor: N.P. Balakrishnan, Retd. Botanical Survey of India, Coimbatore, India.

Date of publication: 26 September 2013 (online \& print)

Manuscript details: Ms \# 03638 | Received 24 May 2013 | Final received 02 September 2013 | Finally accepted 07 September 2013

Citation: C. Udhayavani \& V.S. Ramachandran (2013). On the occurrence of Memecylon clarkeanum Cogn. (Melastomataceae) - a vulnerable species from Nilgiris, Tamil Nadu, India. Journal of Threatened Taxa 5(13): 4811-4813; http://dx.doi.org/10.11609/JoTT.03638.4811-3

Copyright: @ Udhayavani \& Ramachandran 2013. Creative Commons Attribution 3.0 Unported License. JoTT allows unrestricted use of this article in any medium, reproduction and distribution by providing adequate credit to the authors and the source of publication.

Funding: Self funded.

Competing Interest: Authors declare no competing interest.

Acknowledgements: The authors wish to thank Dr. S. Manian, Professor and Head, Department of Botany, Bharathiar University, Coimbatore for providing necessary facilities to carry out the research work in the department. The senior author is grateful to Prof. M.B. Vishwanathan, Department of Plant Science, Bharathidasan University, Tiruchirappalli for his help in identification.

The publication of this article is supported by the Critical Ecosystem Partnership Fund (CEPF), a joint initiative of I'Agence Française de Développement, Conservation International, the European Commission, the Global Environment Facility, the Government of Japan, the MacArthur Foundation and the World Bank. 


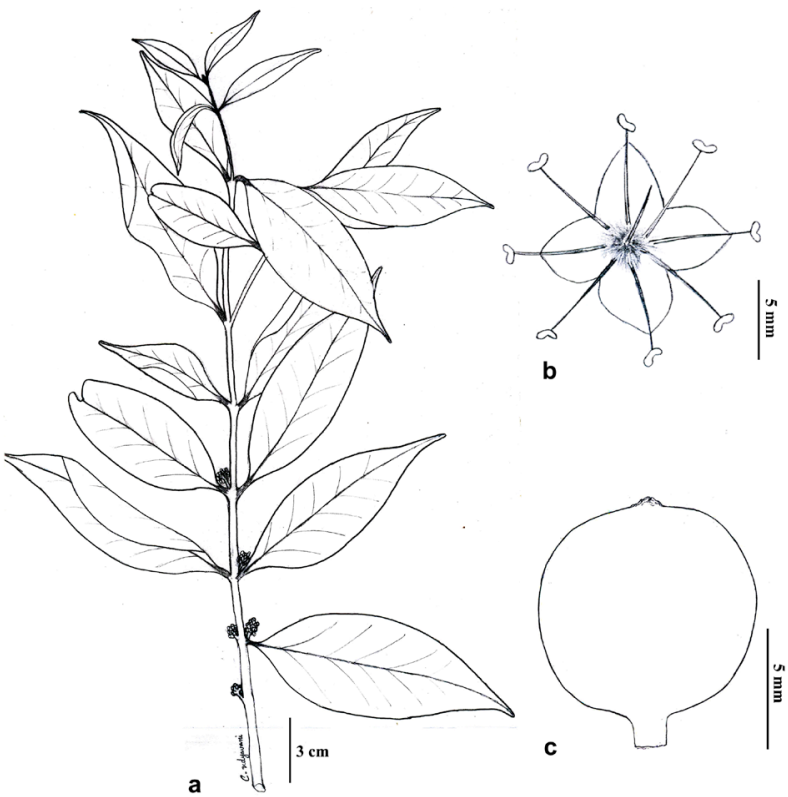

Figure 1. Memecylon clarkeanum Cogn. (C) C. Udhayavani a - habit, b - flower, c - fruit.

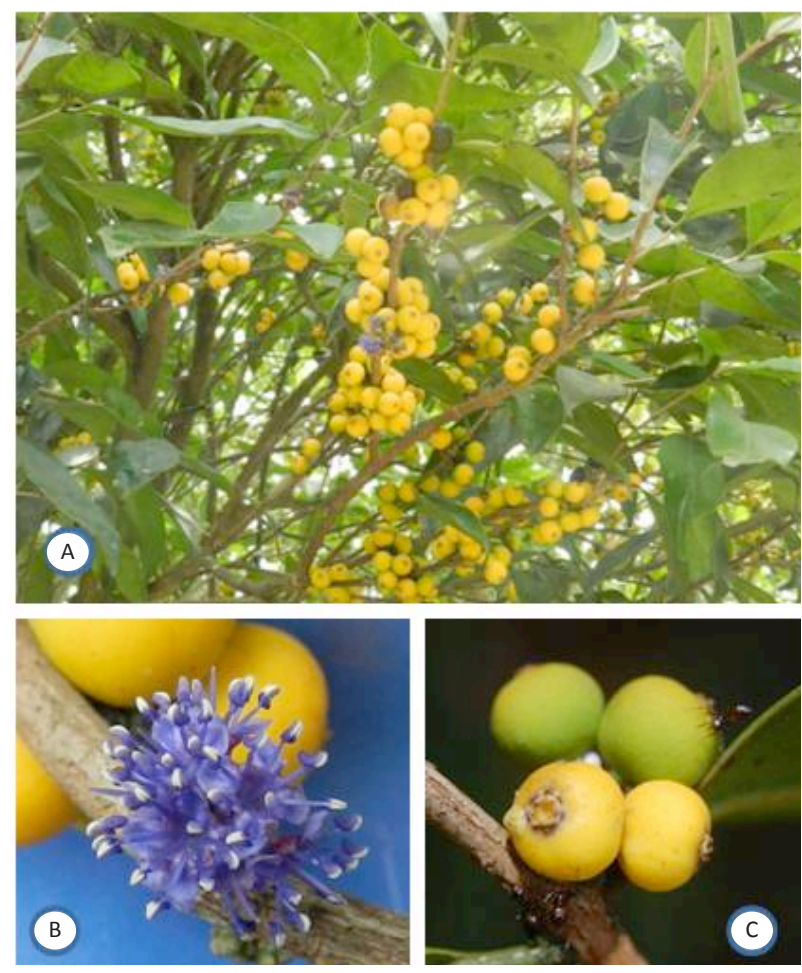

Image 1. Memecylon clarkeanum Cogn. (C) C. Udhayavani A - Habit; B - Flower; C - Fruit

var. latifolia Clarke in Hook. f., Fl. Brit. India 2: 560. 1879.

A large shrub, up to $3 \mathrm{~m}$ high. Stems and branchlets subterete; bark brownish-grey, fissured. Leaves opposite; petiole stout, 7-9 $\mathrm{mm}$ long; elliptic to lanceolate, widest below the middle, $6-12 \times 2.5-5 \mathrm{~cm}$, cuneate at base, slightly revolute along margins, acute to acuminate at apex, glossy above, pale beneath, midrib with indistinct intramarginal and lateral veins, drying dark green on both sides; foliar sclereids filiform. Inflorescence a fascicle, congested on the leaf axils and at leafless nodes; pedicels absent or shorter than the receptacle; bracts ovate-lanceolate, ca. $1.5 \mathrm{~mm}$ long, light green. Flower ca. $4 \mathrm{~mm}$ across, pale blue; buds acute. Calyx campanulate or cup-shaped, ca. $2.5 \mathrm{~mm}$ across, truncate and often with four shallow slits, yellowish; disc smooth or shallowly striate. Petals four, broadly elliptic-obovate, shortly clawed at the base, acute at apex, $2 \times 2.2 \mathrm{~mm}$, pale blue. Stamens eight, equal, filaments slender, ca. $5.5 \mathrm{~mm}$ long, yellowish-white, anthers curved, ca. $2 \mathrm{~mm}$ long. Ovary unilocular, ca. 11 ovules, placentation freecentral, style subulate, ca. $5 \mathrm{~mm}$ long, stigma simple. Fruits globose, berry, $0.8-1 \mathrm{~mm}$ across with persistent calyx, yellowish-green; seed 1 .

Specimen examined: BU 5325, 01.iv.2013, Devala, Nilgiri District, Tamil Nadu, India, coll. C. Udhayavani.

Flowering and Fruiting: November-May. 


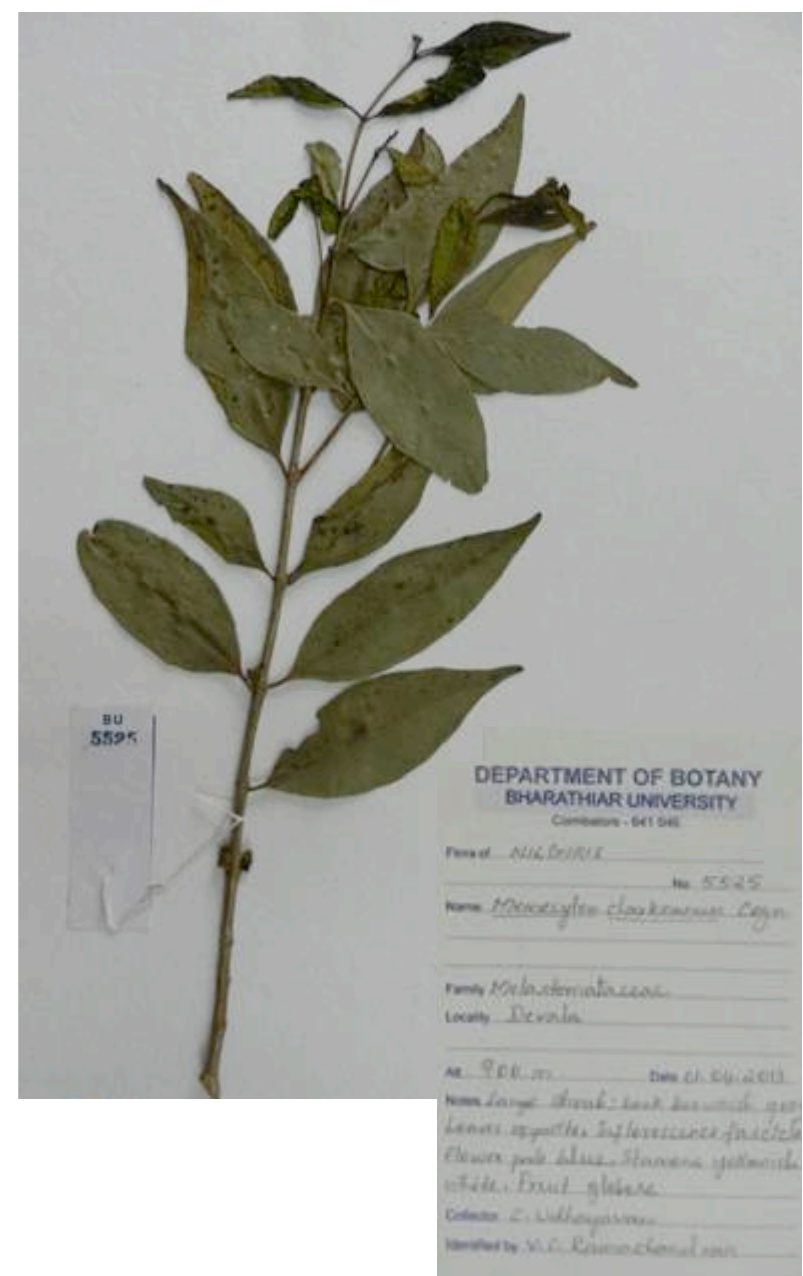

Image 3. Herbarium sheet of Memecylon clarkeanum Cogn.

Distribution: India (Kerala and Tamil Nadu) and Sri Lanka.

Ecology: It was collected from the degraded forest area of Devala near tea plantations. Only two individuals were observed in the study area.

Associated species: Achyranthes aspera L., Polygonum chinense L., Artocarpus heterophyllus Lam., Urena lobata L., Aporosa lindleyana (Wight) Baill., Strobilanthes sp.

Conservation status: Vulnerable (IUCN 2012).
Notes: In the study area only two individuals were noticed. Since they occur near tea plantations, there would be severe threats from biotic interference. Hence these two individual plants are to be protected by the forest department.

\section{REFERENCES}

Bremer, K. (1979). Taxonomy of Memecylon (Melastomataceae) in Ceylon. Opera Botanica 50: 1-32.

Bremer, K. (1987). Melastomataceae, pp. 157-240. In: Dassanayake \& Fosberg (eds.). Revised Handbook of Flora Ceylon-6. Oxford and IBH publishing Co. Pvt. Ltd., New Delhi.

Clarke, C.B. (1879). Memecylon, pp. 553-566. In: Hooker, J.D. (ed.). Flora of British India-2. L. Reeve \& Co. London.

Cooke, T. (1901). The Flora of the Presidency of Bombay-Volume I. Taylor \& Francis, London, 534-535pp.

Gamble, J.S. (1919). Flora of the Presidency of Madras. Adlard \& Sons Co. Ltd., London, pp. 503-505.

IUCN (2012). IUCN Red List of Threatened Species. Version 2012.2. <www.iucnredlist.org> downloaded on 30 April 2013.

Mabberley, J.D. (2008). Mabberley's Plant-Book: A Portable Dictionary of Plants, Their Classification and Uses. Cambridge University Press, Cambridge, 537pp.

Manickam, V.S., C. Murugan, G.J. Jothi \& V. Sundaresan (2007). Memecylon courtallense - a new species (Melastomataceae) from Courtallum Hills of Tamilnadu, India. Indian Journal of Forestry 30(1): 77-80

Mohanan, N., N. Ravi, N.K. Raj \& T. Shaju (2001). A new species of Memecylon (Melastomataceae) From India. Nordic Journal of Botany 21(5): 493-496; http://dx.doi.org/10.1111/j.1756-1051.2001. tb00803.x

Murugan, C. \& R. Gopalan (2006). Four additions to Indian Memecylon L. (Melastomataceae) from south India. Indian Journal of Forestry 29(1): 105-108.

Kumar, E.S.S., R. Antony \& A.E.S. Khan (2003). Memecylon agastyamalaianum (Melastomataceae) - a new species from India. Botanical Bulletin of Academia Sinica 44: 175-177.

Sasidharan, N. (2004). Biodiversity Documentation for Kerala Part 6: Flowering Plants. Kerala Forest Research Institute, Peechi, 181182pp.

Sivu, A.R., M.K.R. Narayanan, E.S.S. Kumar, K.A. Sujana, N.S. Pradeep, N.A. Kumar \& A.G. Pandurangan (2012). Memecylon clarkeanum Cogn. (Melastomataceae) - a threatened species, new record for India. Taiwania 57(3): 327-330.

Viswanathan, M.B. \& U. Manikandan (2001). A new species, Memecylon mundanthuraianum of Melastomataceae from India. Nordic Journal of Botany 21(3): 259-262; http://dx.doi. org/10.1111/j.1756-1051.2001.tb00765.x

Vivekananthan (1983). Melastomataceae, pp. 169-170. In: Nair, N.C. \& A.N. Henry (eds.). Flora of Tamil Nadu, India. Analysis: Series 1. Vol. I. Botanical Survey of India, Coimbatore. 